\title{
Food price volatility and hunger alleviation - can Cannes work?
}

\author{
Stefan Hajkowicz ${ }^{1 *}$, Christine Negra², Paul Barnett ${ }^{1}$, Megan Clark ${ }^{3}$, Bronwyn Harch ${ }^{1}$ and Brian Keating ${ }^{1}$
}

\begin{abstract}
Recent years have seen global food prices rise and become more volatile. Price surges in 2008 and 2011 held devastating consequences for hundreds of millions of people and negatively impacted many more. Today one billion people are hungry. The issue is a high priority for many international agencies and national governments. At the Cannes Summit in November 2011, the G20 leaders agreed to implement five objectives aiming to mitigate food price volatility and protect vulnerable persons. To succeed, the global community must now translate these high level policy objectives into practical actions. In this paper, we describe challenges and unresolved dilemmas before the global community in implementing these five objectives. The paper describes recent food price volatility trends and an evaluation of possible causes. Special attention is given to climate change and water scarcity, which have the potential to impact food prices to a much greater extent in coming decades. We conclude the world needs an improved knowledge base and new analytical capabilities, developed in parallel with the implementation of practical policy actions, to manage food price volatility and reduce hunger and malnutrition. This requires major innovations and paradigm shifts by the global community.
\end{abstract}

Keywords: Food price volatility, food security, hunger alleviation, policy responses, G20 action plan, Cannes Summit

\section{Background}

People are becoming increasingly dependent on global and regional markets for the supply of food. In 1961 imports of cereals in global markets averaged at 26 kilograms per person per year. By 2009 this had increased to 46 kilograms per person per year; a 77 percent increase over five decades [1]. There are few published estimates on the extent of worldwide subsistence production versus market dependency. Our rapidly urbanizing world has 3.5 billion people, or 50.5 percent of the global population, living in cities [2]. This urban population is highly reliant on markets for the provision of food. One early estimate suggests that in developing-country rural areas around half the population are smallholder farmers with up to three hectares of cropland [3]. Many in the remaining population would rely on markets to some extent. Household expenditure on food, as a percentage of total expenditure, is 58.7 in India, 60.6 in Indonesia, 74.8 in Kenya and 81.6 in Rwanda [4].

\footnotetext{
* Correspondence: Stefan.Hajkowicz@csiro.au

${ }^{1}$ CSIRO, Ecosciences Precinct, PO Box 2583, Brisbane, Queensland 4001, Australia

Full list of author information is available at the end of the article
}

Households that spend most of their income on food are vulnerable to price increases.

These observations suggest that food price movements in global and regional markets have a significant impact on hunger. The Food and Agriculture Organization (FAO) global food price index represents a basket of major food groups weighted by average export shares. In February 2011, this index surged 41 percent over eight months to an all time high of 238 points. In addition to overall increases, food prices have become more volatile. In 2007/2008 the world experienced another unusually rapid surge in food prices. The true impacts on the world's poor are unknown. Some estimates suggest that between 75 and 130 million additional people suffered malnutrition [5]. From 2003 to 2007, the number of undernourished people increased from some 848 million to 923 million, largely because of the food-price crisis during this period [6]. Today almost one billion people are undernourished worldwide [7]. The situation has urgent regional dimensions. At the time of writing this paper, UNICEF estimates 320,000 children in East Africa are severely malnourished and at risk of death unless they receive help [8].

\section{Biomed Central}


The international community has recognized the urgency and criticality of food price volatility. It was given attention at the G20 meetings in Paris on 22 and 23 June 2011 and in Cannes on 3 and 4 November 2011 with national governments agreeing to action. The International Food Policy Research Institute [9], the World Bank, the Organization for Economic Cooperation and Development, the Food and Agriculture Organization and other branches of the United Nations are a few of the many international agencies with publications and policy statements on food price volatility [10]. The issue has also been investigated by national governments [11,12]. However, since the devastating 2008 surge, prices have risen even more and remain highly unstable. The problem is far from solved and is likely to remain a high priority for the world over the coming decade.

\section{High and volatile food prices}

Both high and volatile prices create challenges for policy makers and the global community (Figure 1). Food price volatility is the extent to which food prices change over time. It is measured by price variation. We base our definition of price variation on the interagency report to the G20 led by the FAO [10].

If $\mathrm{p}_{\mathrm{t}}$ is the price of a food commodity in time period $\mathrm{t}$ (where $\mathrm{t}$ can represent hours, days, months, years etc.) then price variation $(v)$ may be defined as:

$$
v=\frac{p_{t}-p_{t-1}}{p_{t-1}}
$$

When the absolute value of $v$ is large, we have high variation and volatile prices. When the absolute value of $v$ is small, we have low variation and more stable prices. In practice, economists often measure volatility using the standard deviation of logarithmic prices over consecutive time intervals [13]. More detailed definitions of price volatility and related terms are contained in Appendix A of the inter-agency report to the G20 [10]. Volatile prices create uncertainty and risk for farmers, traders, wholesalers, retailers, consumers and governments [14]. Risk can dampen investment which, in turn, can decrease production. Price increases are associated with hunger and malnutrition among the world's poor people [10]. Analysts often refer to sudden, large and unexpected price increases as "surges". Recent research finds that high food prices, but not necessarily price volatility, is associated with political unrest, particularly in low income countries $[15,16]$. This paper is concerned with both price volatility and price increases. However, when referring to "volatility" the G20 objectives are typically focused on the price peaks and surges, as opposed to troughs, because the peaks are associated with hunger and political instability and prompt a policy response.

The recent price surges of 2008 and 2011 are widely considered "global crises" [17]. One possibility is that the world is experiencing a short and temporary period of high and volatile prices. Another possibility is the current situation persists or worsens over the coming decade. Price volatilities of the most important grains have increased in recent years and there is likelihood of further sharp price movements [13]. The Organization for Economic Cooperation and Development (OECD) and FAO forecast world wheat and rice price increases of 14 and 35 percent by 2020 [14]. Additional pressure stems from highly variable energy prices, which are transmitted into food markets [17].

Some research concludes that future decades will see more food price spikes and the alleviation of hunger will

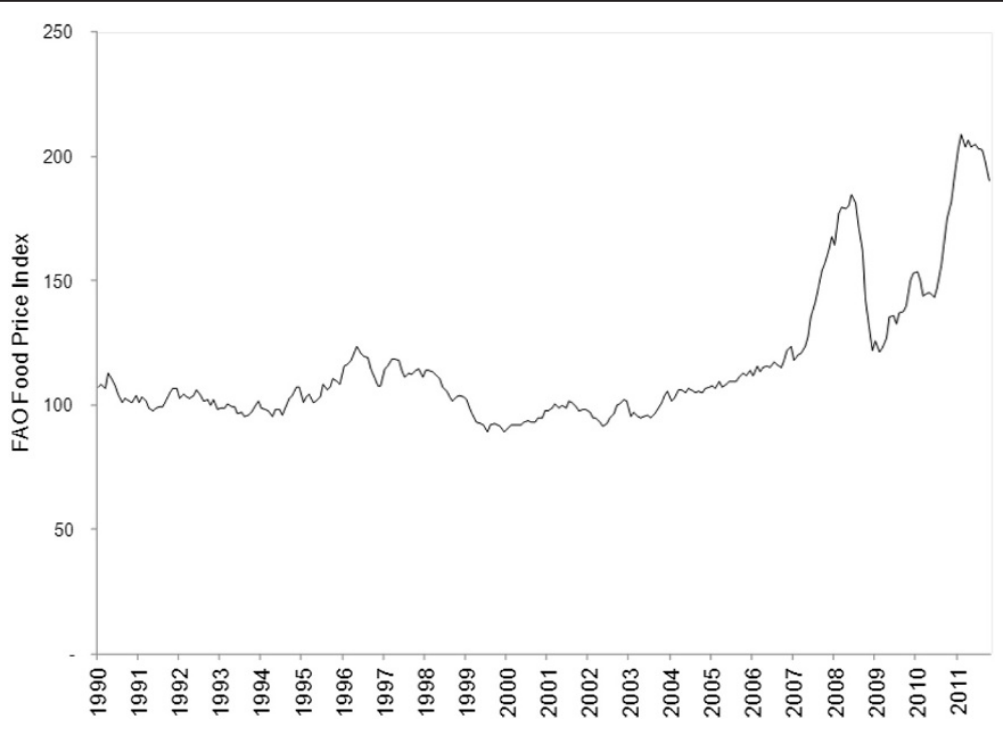

Figure 1 World food price index (Food and Agriculture Organization Annual real food price index 2002 to 2004=100). 
depend on the responsiveness and vigilance of world governments [18]. Several global trends create concerns. The world population is forecast to grow from 7 billion persons currently to 9.3 billion by 2050 [19]. Income growth in Asia is resulting in increased protein consumption, which requires greater land and energy inputs. Meat consumption in developing countries has been growing at over five percent per year over the last few decades with an expectation of continued future growth [20]. It is estimated that 12 million hectares of productive agricultural land, capable of producing 20 million tons of grain, are lost each year to land degradation [21]. Future food production is likely to be impacted by more frequent and severe weather events associated with climate change [22].

Other commodity markets are also experiencing unstable prices. The forces that drive food price movements are similar to those that drive energy and mineral commodity price movements $[23,24]$. The previous decade has seen commodity prices increase to an extent not experienced for the past 40 years. The price growth has been accompanied by an increase in volatility across most commodities [25]. The United Nations Conference on Trade and Development's (UNCTAD) global commodity price instability index (Figure 2) shows the latter half of the previous decade (2006 to 2010) experienced greater volatility than the first half (2001 to 2005). The instability index is measured as the percentage of deviation of commodity prices from their exponential trend levels for a given time period.

At this stage, there are no data providing evidence of a long-term shift in commodities' markets. Analysis of commodity price movements over centuries, since the year 1700 until now, finds no evidence of a permanent volatility increase over history [27]. The UNCTAD data available since 1960 also reveal no long-term trend other than a period of increased price stability during the 1960 s compared to subsequent decades. Nevertheless, food prices today are higher than they have been for decades and the issue is associated with widespread human suffering and political unrest. Food price increases and price volatility are likely to stay high on the political agenda for some time to come.

\section{Causes of food price surges}

An ability to mitigate the consequences of food price surges hinges upon our understanding of the causes. Food price movements are caused by myriad drivers of supply and demand (Figure 3). In addition to supply and demand is a poorly understood speculative, or "bubble", component. A vast body of research has been conducted into the causes of food price movements and, in particular, the recent 2008 food price surge [5,12,13,17,28]. Many global agencies and national governments have also explored the issue $[9,11,14,29]$. Nevertheless, understanding of the causes of food price movements remains partial and contested. The 2011 price surge, higher than in 2008, revealed additional possible causes, which are still finding their way into the research literature. A comprehensive listing of all factors which potentially cause food price movements would contain hundreds of entries. In this section, we explore arguments for and against some of the major proposed theories.

\section{Low food stocks}

Food prices are particularly sensitive to supply shifts when stocks are low [30]. A review of the causes of food price surges for the UK Government states (p120) "if a single

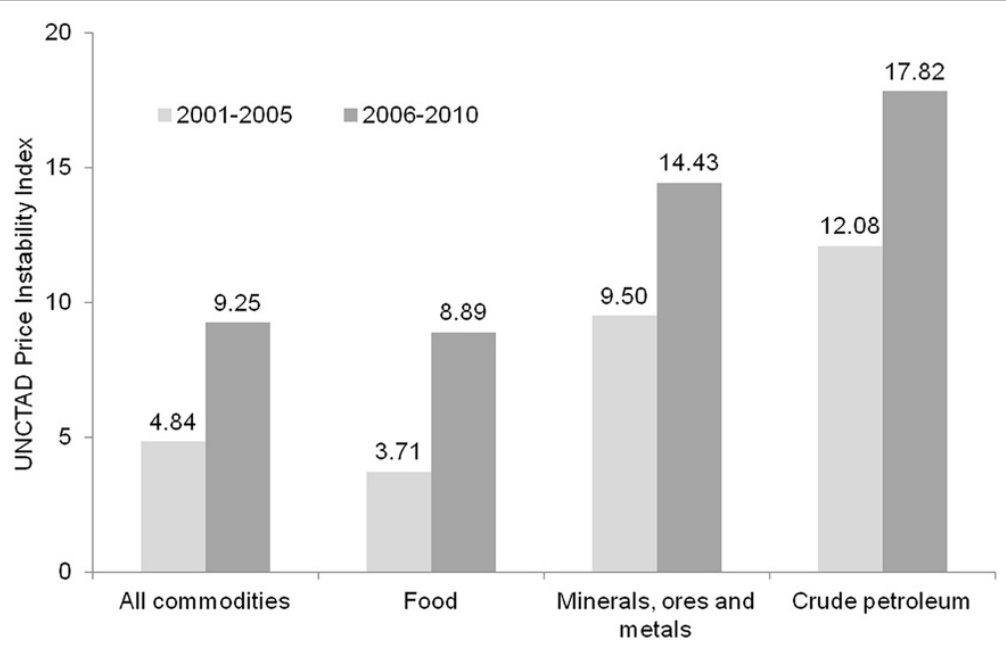

Figure 2 Commodity price instability in the previous decade. Data source: United Nations Conference on Trade and Development [26]. 


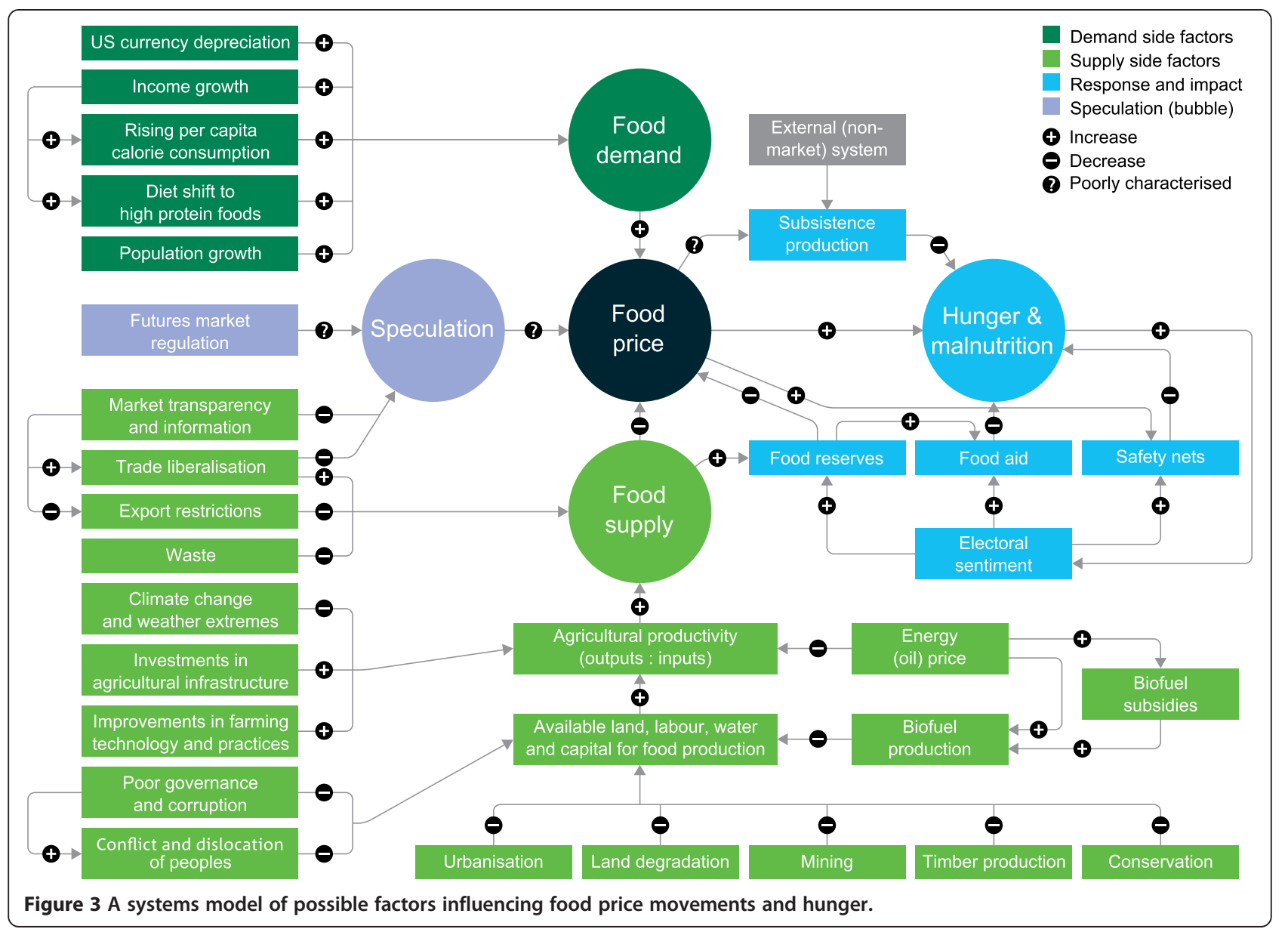

factor is to be identified as the cause of the recent price spikes, it has to be low stocks" [12]. The same study finds that 42 percent of the variance in food prices during 2006 to 2008 is explained by low stock to use ratios. Stocks were at low levels in the lead up to the 1973 and 2008 food price surges. However, it may be questioned whether low food stocks are a cause or consequence of price increases [28]. In 2006, global food stocks, especially wheat, were at their lowest level since the early 1980s [9]. It is possible that factors constraining supply, such as drought in Australia, led to higher utilization of storage ratios in the lead up to the 2008 price surge. From this perspective, low stocks are a consequence of underlying supply and demand forces which cause food price volatility. Regardless of whether it is a cause or consequence, it is clear from previous research that food stock to use ratios play an important role [30,31].

\section{Biofuel production}

One percent of the world's arable land is devoted to biofuel production. By 2030 this is projected to become 2.5 to 3.8 percent under low and high estimates [32]. The growth in biofuel production will result from market forces and from government subsidies. There is a widespread view that biofuel production, and subsidies, increase the severity of food price surges [9,33-35]. Some recent studies have examined the impact of biofuel production on the 2008 food price spike. One of these employs a price dynamic supply and demand model to find that the "underlying upward trend" in food prices is due to increasing demand for ethanol [36]. An earlier analysis of time series data relating to global food prices and biofuel production finds no direct long-run relationship and "limited if any" short run relationship [37]. Another study, using similar methods, finds that biofuel production had a 3 to 30 percent contribution to the 2008 food price spike [38]. In the future, rising energy prices, responding to growing global energy demand, will boost the demand for biofuel. This may be offset somewhat by the use of second generation biofuels (for example, cellulosic ethanol), which are produced from non-food crop biomass. Nevertheless, any type of biofuel production is likely to place at least some upward pressure on food prices because it will consume scarce land, water, labor and capital resources that would otherwise have been invested in food production. 
Export restrictions, trade barriers and market distortions

With the objective of stabilizing domestic prices, countries may sometimes impose export bans, export restrictions and export taxes on food products. While this may stabilize prices domestically and in the short term, it has been shown to substantially increase food prices globally and, especially, for countries heavily dependent on imports [17,28]. In the lead up to the 2008 price spike, Argentina, Russia, Ukraine, Kazakhstan and India imposed wheat export restrictions. Export restrictions for wheat and rice are widely considered a primary cause of the price spike [5]. It is estimated that elimination of export restrictions would reduce grain-price surges by as much as 30 percent [9]. There would seem to be a greater degree of consensus that export restrictions, as opposed to other proposed causes, drive food price volatility.

\section{Droughts}

In the lead up to the 2008 price spike, the world experienced some climatic events which significantly lowered production. For example, in the lead up to the price spike, droughts in Australia saw wheat production fall some 56 per cent between 2000 and 2007 [39]. This had an effect on global markets since Australia is the world's second largest wheat exporter, accounting for 15 per cent of wheat trade on the world market [40]. Poor growing conditions were also experienced in the United States, Russia and Ukraine [28]. There would seem to be relatively strong consensus among researchers that weather patterns can exacerbate food price volatility. However, the magnitude of the impact at the global scale is unclear. There have been few attempts to analyze lead-lag relationships in global environmental variables and food prices.

\section{Income growth, especially in India and China}

Both the Indian and Chinese economies experienced rapid growth in the decades preceding the 2008 price spike. There is a view that income growth in these countries led to changing patterns of food consumption, with a shift towards proteins and some vegetables, which fueled a global food price surge [41]. Meat requires greater quantities of land, energy and other resource inputs to produce the same calorific value as rice, soybeans or grains. However, there is some debate about the extent to which income and demand growth has buoyed prices. Some researchers reject this theory because they argue India and China have long been self sufficient in food. China imported less wheat in 2000 to 2007 (33.8 million tons) than in the proceeding eight years (40.3 million tons) [28]. However, China has rapidly increased other food imports. Soybean imports in China increased sharply during the lead up to the 2008 price surge. China imported 181 million tons of soybeans during 2000 to 2007 compared to 32 million tons in the proceeding eight years [1]. The increased demand would have impacted global soybean prices. The OECD and FAO observe that strong income growth in China, India and other rapidly developing economies is shaping commodity markets and will be a permanent factor influencing price [14].

\section{Depreciation in the US dollar}

It has been shown that depreciation of the US dollar increases commodity prices with an elasticity between 0.5 and $1.0[42,43]$. This is because the majority of commodity exchanges are denoted in US currency. During 2002 to 2008, the US dollar depreciated by 35 percent against the Euro. If 0.75 is taken as the midpoint elasticity, depreciation of the US dollar contributed 20 percent to rising food prices between 2002 and 2008 [44]. There is relatively strong consensus that exchange rate movements are important factors impacting food prices. However, the impact of exchange rate movements on commodity prices overall remains hard to quantify and some researchers argue that depreciation of the dollar has not been sufficiently large or far reaching to be a major contributing factor $[12,45]$.

\section{Urbanization}

During 1975 to 2009, the world urban population grew at an average annual rate of 2.4 percent compared to the rural population which grew at 0.85 percent. These rates are forecast to be 1.76 and 0.12 percent during 2009 to 2025 [2]. Urbanization is impacting food production via the conversion of productive arable land into towns and cities. The rate of urbanization is particularly rapid in China. It is estimated that 6.72 million hectares, or 5.1 percent of China's total arable land, was lost to industrial or urban purposes during the seven-year period 1996 to 2003 [41]. However, urbanization is a gradual and ongoing process present during the previous and forthcoming centuries. While urbanization is likely to place upward pressure on food prices, it is unlikely to cause sudden price surges or price volatility.

\section{Speculation on food commodity futures markets}

There is considerable debate about whether or not speculation on food commodities markets exacerbates food price surges. Most economists and financial analysts agree that speculation cannot drive prices up in the long run - over a decade or more [46]. However, there is a possibility it may impact short-term price movements. Some lead-lag studies suggest that speculation places upward pressure on food price volatility. One study found that unexpected increases in futures trading volumes leads to a subsequent increase in cash price volatility for most commodities [47]. A similar lead-lag study by the International Food Policy Research Institute 
is not conclusive and finds that speculative activity "might" have been influential in the 2008 price spike, but suggests further research is needed [48]. A recent price dynamic model by the New England Complex Systems Institute involving a statistical analysis of price data and futures trades finds that price peaks in 2008 and 2011 are "specifically due to investor speculation" [36]. Other researchers argue there is "compelling" evidence that the recently expanded food-commodity derivatives market led to speculative investment leading to increases in global prices in excess of normal supply-demand forces [49]. However, there are opposing perspectives. Some suggest futures markets may have exacerbated price volatility but are unlikely to be a leading cause and there is little evidence to support the link between futures markets and "real" supply-and-demand factors [28]. A stronger position argues that speculation is often unfairly attacked during periods of increased market volatility and that the "bubble" argument for high food prices "does not withstand close scrutiny" [50]. There is also a view that speculation has positive impacts by facilitating smooth functioning of global food markets and stabilizing trade [51].

\section{Oil price rises}

World food prices and world oil prices move in unison. It has been observed that modern agriculture uses land to convert petroleum into food [52,53]. One estimate suggests that industrialized farming systems use $10 \mathrm{cal}-$ ories of fossil fuel to produce 1 calorie of food energy $[54,55]$. Therefore, a rise in crude oil prices typically increases the cost of food production, steepens the supply curve, and increases food prices [24]. An analysis of crude oil and commodity price data from 1965 to 2005 finds that a 10 percent increase in the crude oil price leads to a 3.3 percent increase in fertilizer cost and a 1.8 percent increase in food price [56].

\section{Climate change, water scarcity and future food prices}

Climate change and water scarcity have the potential to place significant upward pressure on food prices, and increase price volatility, over the coming decades. Both warrant special attention because they have the capability to impose fundamental constraints on the world's ability to produce food. Climate change and water scarcity impact all the variables in the food price systems model (Figure 3). Furthermore, there is considerable uncertainty about the extent that climate change and water scarcity will impact food production systems.

Prior research establishes a clear and unambiguous link between localized climate extremes, such as droughts and floods, local food security and local food prices. The 1998 flood in Bangladesh created a shortfall of 2.2 million tons of rice production leading to a price surge harming vulnerable households [57]. Cyclone Larry in North Queensland in 2006 destroyed large plantations leading to a 400 percent price increase for bananas across Australia [58]. It is estimated that food costs in Louisiana increased by 11.5 percent following hurricane Katrina in 2005 [59].

There is also an established link between global climate patterns and food price volatility [60]. Droughts in Australia and poor growing conditions in Russia, the United States and the Ukraine over several years significantly contributed to the 2008 spike in global wheat prices [28]. The El Niño-Southern Oscillation (ENSO) cycle is associated with global climatic extremes, such as flooding and drought. A one-standard deviation change in ENSO is associated with a commodity price inflation of 3.5 to 4 percentage points and ENSO accounts for almost 20 percent of commodity price movements over several years [61]. A study of the south-eastern agricultural regions of the United States finds that ENSO phases explain an average shift of US \$212 million or 25.9 percent of the value of corn production in that region [62]. A study of Florida's agricultural regions found lower yields of tomatoes, bell peppers, sweet corn and snap beans and higher prices for bell peppers and snap beans during El Niño as opposed to La Niña winters [62]. However, the impact of ENSO on the macroeconomy is less clear. An examination of co-cyclicality of ENSO and inflation and economic growth within the US economy from 1984 to 1999 reveals that ENSO had no discernable impact on the gross domestic product [63].

While the link between extreme climate events and food prices, both regionally and globally, has been identified through prior research, the link between human induced climate change (that is, the greenhouse effect) and global food prices is not yet known. One study estimates that between 5 million and 170 million additional people will be at risk of hunger by 2080 due to climate change [64]. This study also suggests extreme weather under climate change scenarios is likely to destabilize food production, but the researchers do not report quantitative estimates. It is worth noting that the impacts of climate change on food production may not be universally negative. Some areas of the world will experience changed rainfall patterns and more favorable growing conditions. However, the aggregate global crop production is likely to decrease [65].

The Intergovernmental Panel on Climate Change (IPCC) Fourth Assessment notes that current models used to quantify the impacts on food security $[66,67]$ do not yet cover potential changes in the stability of food supplies. The link to food price volatility is not mentioned. There are calls for new assessment methods that place climate change into the context of other factors which drive food prices [68]. 
One such factor is water scarcity. Data from the International Water Management Institute (IWMI) reveals the extent of this dilemma [69] (p10). It estimated that 1.2 billion people live in regions with insufficient water to meet human needs. It is also estimated that 1.6 billion people live in water-scarce river basins with inadequate financial and human capacity to develop future water resources. The demands on limited water resources will increase as the world population grows, emerging economies industrialize and new cities are built. This will place more pressure on water needed for agriculture. Water is a non-substitutable input for many forms of agricultural production. Agriculture currently uses 70 per cent of the world's water [69]. The IWMI describe a scenario involving a 40 percent increase in the withdrawals of water for agriculture to feed a growing population by 2050 [70]. Combined modeling by IFPRI and IWMI predicts that under a water crisis scenario, where supply falls well short of demand, crop prices will be 1.8 times greater than business-as-usual for rice, 1.7 times for potatoes, 1.6 times for soybeans and more than double for all other crops by 2025 [70]. If this scenario occurs, water scarcity will be a primary driver of food price increases. The solutions to water scarcity have been explored by the IWMI and include changes in governance, agricultural production systems and investment in infrastructure [70].

\section{Can Cannes work?}

Food price volatility, price increases and food security are firmly established as high priority issues for the G20 and national governments. At their summit in November 2010, the G20 leaders requested a collection of global agencies to examine policy options. The findings were published in June 2011 in a report identifying 10 recommendations by the Food and Agriculture Organization, the International Fund for Agricultural Development, the International Monetary Fund, the Organization for Economic Cooperation and Development, the United Nations Conference on Trade and Development, the World Food Program, the World Bank, the World Trade Organization, the International Food Policy Research Institute and the United Nations High Level Task Force [10].

The matter was given attention at the first Agriculture Ministers meeting in Paris on 22 and 23 June 2011 with subsequent adoption of the "Action Plan on Food Price Volatility and Agriculture" [71]. Later, at the G20 Cannes Summit on 3 and 4 November 2011, the G20 annexed a declaration [72] to implement five objectives of the action plan [73] as listed below. In this section, we discuss some of the challenges and capability requirements relating to implementation of the five objectives in the action plan by the global community.

\section{Improving agricultural production and productivity}

Based on assumptions about population growth, changing diets and agricultural systems, the FAO forecasts that food production needs to increase by 70 percent by the year 2050 to meet demand. This includes growth in annual cereal production from 2.1 billion tons to 5.1 billion tons and meat production from 200 million tons to 470 million tons [74]. To tackle food price surges, production systems must also become more resilient with greater diversification and an ability to handle external shocks. Arguably the most effective long-term defense against food price increases is building a resilient, efficient and diversified agricultural sector.

Public expenditure on agricultural production systems in developing countries worldwide has increased from US $\$ 111.8$ billion in 1980 to US $\$ 225.6$ billion in 2002 [75]. When compared to world population growth, income growth and increasing food demand over the same period, the growth in expenditure is modest at best. Furthermore, the effectiveness of this expenditure is widely debated and researchers have identified numerous policies and strategies to achieve better outcomes [76,77]. Some economic studies conclude the world is chronically under-investing in research and development to improve agricultural production systems [78]. Following a period of "stagnation" during the 1990s, investment in agricultural research and development in Sub-Saharan Africa increased by 20 percent over the period from 2001 to 2008. However, the growth in expenditure occurred in only a few countries and investment in many other countries within the region has fallen to dangerously low levels [79]. It is estimated that developing countries need to invest US \$9.2 trillion over the 44-year period from 2007 to 2050 to meet the FAO baseline agricultural outlook [80].

In the current world economic climate with the G20 and other nations burdened by high debt levels and domestic austerity measures, the discovery of new funds for agricultural development will be challenging. This heightens the importance of targeting. Increased, and better targeted investments are needed because improved production systems may be the most effective long-term approach to food price stabilization. In addition to the economic challenges, the world faces climate change and water scarcity dilemmas. As yet there is no convincing means by which food production can increase by 70 percent, taking into account all environmental, technological and institutional constraints. In order to achieve this objective, the G20 and other national governments need to invest more resources in agriculture and food production. The world also needs better information about where, how and when to spend money to improve agricultural production capabilities. 


\section{Increasing market information and transparency}

One of the main actions to occur under this objective is the creation of an agricultural market information system (AMIS), which was launched in December 2011 [81]. The basic premise is that better information will lead to wiser investment choices and more stable markets. Information can also limit irrational speculation and panic buying associated with price bubbles. Most economists would agree that the provision of accurate information and transparency improves the functioning of markets. In addition to AMIS, the G20 describes other information tools, including the use of satellite remote sensing to forecast crop yields, famine early warning systems and vulnerability mapping. For example, the G20 declaration notes the "Global Agricultural Geomonitoring Initiative", which will use satellite remote sensing for enhanced crop production projections [72].

As the databases develop, there is a parallel requirement to develop integrated social, economic and environmental systems models. Many of the required models exist but most are focused on components and subsystems of the food price and food security system. Linkage of these models from different systems and scales has the capacity to improve understanding of interactions among social, economic and biophysical systems $[82,83]$. Such approaches may assist in the understanding of how global price changes impact domestic prices and also establish understanding of the mechanisms by which food price surges translate into hunger and malnutrition. An example of one effort to achieve this comes from the Agricultural Model Intercomparison and Improvement Project [84]. Commencing in March 2011, this project draws together agronomic and economic models into a common framework to explore the impact of future climate change on food security.

Another interesting angle involves the use of social media, online content and automated text searching and interpretation algorithms to forecast future food security conditions. The United Nations Global Pulse project commenced in 2009 [85]. This initiative uses real-time information sourced from the internet to predict global crises and inform decision makers about the best ways to proactively respond. Forecasting food price surges, and food insecurity, is an important area of activity for the Global Pulse initiative. The Global Pulse e-bread initiative uses "web scraping" algorithms to record and interpret monthly bread prices from online retailers. These data can potentially forecast future price movements [86]. The rapidly expanding fields of data mining, text analysis and sentiment analysis attack the challenge of forecasting price movements via a markedly different approach to conventional econometric models. This creates the possibility of new insights. Another recent initiative called Planetary Skin $[87,88]$ makes use of remote sensing data combined with other datasets to analyze and forecast environmental trends. Innovations in mixing satellite data with other environmental resource and socio-economic data at the global scale could provide new capabilities for forecasting food security crises.

The development of improved market information is tractable and is already occurring. There is solid economic theory supporting the notion that improved, and more transparent, information leads to better functioning markets. However, to realize the benefits of rich data relating to agricultural markets and production, there will be a requirement for a new generation of systems models. As the amount of data expands rapidly, some of the best insights into food price movements and food security may be obtained via the development of innovative ways to combine and interpret the data.

\section{Reducing the effects of price volatility for the most vulnerable}

This objective refers to a range of defensive measures, including food aid, safety nets, financial risk management, and capacity development for vulnerable countries. In crisis situations, where people face starvation, food aid and safety nets are the primary means to mitigate harm. Researchers have identified the need to improve both these policy mechanisms.

Food aid represents less than 0.2 percent of total world food production [89]. Therefore, food aid has a minor impact on global food prices and food security. However, it can make a significant difference at the margin and can stabilize prices within localized geographic regions. During 1988 to 2009, global emergency food aid deliveries grew from 2.2 to 4.2 million tons [90]. The critical requirement for food aid effectiveness is targeting [91]. Prior studies present evidence of ineffective targeting where food aid fails to reach a country's most needy, food insecure, citizens [92]. Bilateral food aid has been shown to be poorly targeted, and less effective, than multilateral food aid, which has a counter-cyclical and stabilizing impact on food prices [93]. There are many calls to upgrade global food aid systems. A recent review argues that "existing international mechanisms governing food aid are dysfunctional and outdated" [89]. The researchers conducting this review propose a Global Food Aid Compact which would be more inclusive of recipient countries, specify donor commitments, contain monitoring and enforcement mechanisms and a compulsory code of conduct. There are some positive signals. A recent study shows that since the 1990s donors have become increasingly responsive to recipient countries experiencing violent conflict [94].

In addition to food aid are safety nets. A safety net may be defined as "some form of income insurance to 
help people through short-term stress and calamities" (p90) [95]. Safety nets are a widely used and effective mechanism to protect vulnerable persons against malnutrition and starvation. However, safety nets may also have negative consequences when they are not designed or deployed properly. Ideally, a safety net provides protection during a short term crisis while building long term food self-sufficiency and resilience. Three case studies from southern Africa finds that even 'tiny' income transfers are invested by recipients in education, social networks and the acquisition of productive assets [96]. This tends to suggest that safety nets can protect the poor from price volatility while building longer term self-sufficiency.

To succeed in this objective of the G20 action plan, and protect vulnerable persons, the world needs to achieve better targeting, and overall management, of food aid [97]. To achieve better targeting the FAO [98] identifies three policy priorities involving improved food security assessments; better ongoing monitoring and needs assessment and; improved governance at global, national and regional levels. While considerable work is underway, these policy gaps remain and will act as barriers to improved targeting of food and safety nets until addressed.

\section{Strengthening international policy coordination}

The inclusion of this objective implies the current institutional arrangements need strengthening and better coordination. Episodic breakdown in national and regional food production systems and subsequent food price instability can often be traced back to poor governance [99]. Attempts to improve governance with a view to ensuring food security are widespread [100] and much research has been published on the topic [101]. A large number of international agencies, national overseas aid agencies, charities and domestic governments are active in the food security space. There is no lack of interest. However, the problem of price volatility and food insecurity is worsening. An emerging problem will be coordination. To address this, there is a requirement for studies into global level institutions to identify gaps and redundancies. As yet there are few comprehensive institutional maps of food price volatility relevant organizations.

Another important knowledge requirement relates to trade liberalization. The G20 action plan states support for the conclusion of the Doha Development Round "to a successful, ambitious, comprehensive and balanced conclusion, consistent with its mandate" (p 10/24) [71]. Global agricultural markets are distorted by barriers to trade and production subsidies. From some perspectives, international adoption of free trade through World Trade Organization (WTO) negotiations is the most effective policy mechanism for improving food security [11]. This perspective rests on the argument that free market forces are an effective mechanism for ensuring food supply responds swiftly to demand and, thereby, stabilizes prices and reduces hunger. Economists have greater consensus on the price volatility impacts of certain market distortions and less so on others.

Export and import restrictions are market distortions widely agreed to exacerbate global food price surges. Trust and cooperation between countries are prerequisites for the management of export restrictions. This opens the question about whether food export restrictions should be handled under future WTO agreements. Neither current nor proposed WTO agreements cover agricultural export restrictions [5]. The International Food Policy Research Institute considers this to be the correct approach. They recommend that instead of using WTO mechanisms the international community should form ad hoc forums to establish a code of conduct [9]. This would help build trust and cooperation critical for the management of food export restrictions. Others suggest that formalization of free trade via the WTO is the best approach [11].

There have been many attempts to examine the impacts of trade liberalization on food prices and security. A study of food grain markets in India revealed that removal of barriers to trade, such as export restrictions, decreased price volatility domestically [102]. However, a stochastic dynamic programing model for Southern Africa revealed that regional food prices were more volatile in the absence of government intervention in agricultural markets [103]. Another study of the rice trade between India and Bangladesh finds liberalized trade improves food security for vulnerable people [104]. Some research cautions against moving too far in the direction of free trade given the success of many Asian governments in achieving price stabilization, and food security, via market interventions [105].

A better understanding of the pathways to liberalized trade will increase the chances of the G20 action plan succeeding in its objective to mitigate the negative consequences of food price volatility.

\section{Improving the functioning of agricultural commodity derivatives markets}

Governments can reduce harmful speculation in agricultural commodity futures markets via regulatory controls and the provision of information. Regulatory controls limit the volume of futures trades. One form of such regulation involves increasing margin deposits on futures trades, therefore, increasing the risk, and reducing the prevalence of, speculation. Limiting the positions of traders may also have a calming effect on markets [9]. The provision of information and requirements for transparency can also limit harmful speculation and can reduce market 
manipulation behaviors. The G20 action plan addresses both these dimensions.

The impact of speculation in derivatives markets on commodity price movements is heavily contested. Further research is required to establish a stronger evidence base. Some economists argue there is no convincing reason to link market speculation to the price surges of recent times $[50,51]$. A contrary story is emerging from empirical studies involving lead-lag analyses of trading and price data $[36,47,48]$. These studies are showing us that speculative activity on markets is linked to increased price volatility and significantly contributes to price surges.

The need to provide better information and transparency about markets is widely supported and through initiatives such as AMIS is well underway. A key question for policy makers is whether to regulate or not to regulate. The G20 action plan does not prescribe regulation but rather "strongly encourage(s) G20 Finance Ministers and Central Bank Governors to take the appropriate decisions for a better regulation and supervision of agricultural financial markets" [71] (p14). If there is no link between speculation and food price surges then regulation may be costly and hamper the smooth functioning of agricultural markets. However, if there is a link, then regulation of speculation may be an effective means of reducing price surges and protecting vulnerable people. Which pathway is more risk averse? Given the severity and urgency of the food price crisis some researchers suggest that in the absence of conclusive evidence well designed regulations are the more prudent, and risk averse, way forward [36].

\section{Conclusion}

We conclude that the five G20 Cannes objectives can be effective, but some major innovations are required by the global community. Perhaps the most important shift relates to a renewed recognition by the global community about the importance of the agricultural sector. For many developed economies, agriculture has shrunk over the past century to a few percent of gross domestic product while other sectors, especially services, have risen rapidly. Investment in agriculture in developing countries is widely considered inadequate. However, many of the solutions to food insecurity, global warming and biodiversity loss lie within the agricultural sector [106]. The growing global population, rising food prices and widespread hunger may lead to a resurgence of policy focus on agriculture.

As recognized by the establishment of the Millennium Development Goals, the world is in a long-term food security crisis in which hunger and malnutrition afflict a significant proportion of the global population. Food price spikes exacerbate this crisis. Urgent action is required, but the knowledge base is currently inadequate for the development of low risk, high benefit policy interventions. Trends, such as urbanization, agricultural development, improved transportation systems, changing diets and income growth in Asia, are leading to people's increased reliance on global and regional markets for food provision. This means that price movements can significantly impact hunger and malnutrition rates. Despite much effort over recent decades, the research community is still unraveling the causes, consequences and responses to price surges. A solution requires deep and far reaching change in food production and distribution systems and the governance frameworks that surround them.

While actions need to be taken immediately, there is a requirement for a parallel effort to build a more robust knowledge base and improved analytic capabilities. History is replete with examples of how well intended interventions in markets lead to damaging outcomes, sometimes worse than the original problem being solved. While the current global food production and distribution system is unsatisfactory, it still manages to feed six out of every seven humans. The increasing calls for fundamental and far reaching redesign so we can sustainably feed seven out of seven humans are warranted. However, it would be disastrous if changes to food supply systems worsened the ratio. Without knowledge of how a system responds we always risk side effects that could be worse than the problem being solved. Better knowledge and improved capabilities, alongside immediate actions, will help the G20 action plan achieve its objectives.

\section{Abbreviations \\ AMIS: Agricultural market information system; CCAFS: Climate Change, Agriculture and Food Security; CGIAR: Consultative Group on International Agricultural Research; CSIRO: Commonwealth Scientific and Industrial Research Organization; ENSO: El Niño-Southern Oscillation; FAO: Food and Agriculture Organization; IFPRI: International Food Policy Research Institute; IPCC: Intergovernmental Panel on Climate Change; ISO: International Organization for Standardization; IWMI: International Water Management Institute; OECD: Organization for Economic Cooperation and Development; RSB: Round Table for Sustainable Biofuels; UK: United Kingdom; UN: United Nations; UNICEF: United Nations Children's Fund; UNCTAD: United Nations Conference on Trade and Development; US: United States; WTO: World Trade Organization.}

\section{Competing interests}

The authors declare that they have no competing interests.

\section{Authors' contributions}

All authors have read and approved the final manuscript. SH designed and led the study, structured the concepts, developed the arguments and wrote most of the manuscript. CN, PB, MC, BH and BK wrote parts of the manuscript, identified and developed important concepts, validated and helped design the arguments and initiated, conceived and helped design the study. In addition SH and PB analyzed the data and reviewed background literature and SH, PB and CN co-designed the food price drivers systems diagram.

\section{Authors' information}

$\mathrm{SH}$ is a principal scientist at CSIRO with expertise in geography, economics and decision theory. $\mathrm{CN}$ is a soil scientist with experience in agricultural extension, climate change and food security policy. PB is an impact and 
business development manager with qualifications in resource and environmental management and expertise in geography, information sciences and innovation systems. MC is the chief executive officer of CSIRO with expertise in geosciences, innovation management and technology development. $\mathrm{BH}$ is a statistical scientist with experience in agrienvironmental measurement and monitoring and deputy director of CSIRO's Sustainable Agriculture Flagship. Brian Keating is director of the Sustainable Agriculture Flagship in CSIRO with a background in farming systems science.

\section{Acknowledgements}

This research was funded by the CSIRO and conducted in support of the Commission on Sustainable Agriculture and Climate Change which was convened by the CGIAR Research Program on Climate Change, Agriculture and Food Security (CCAFS). We express gratitude to the many reviewers who provided detailed and thoughtful comments on early drafts of this manuscript.

\section{Author details}

${ }^{1}$ CSIRO, Ecosciences Precinct, PO Box 2583, Brisbane, Queensland 4001, Australia. ${ }^{2}$ Secretariat, Commission on Sustainable Agriculture and Climate Change, Copenhagen, Denmark. ${ }^{3}$ CSIRO, 343 Royal Parade, Parkville, Victoria 3052, Australia.

Received: 19 January 2012 Accepted: 26 April 2012

Published: 7 June 2012

\section{References}

1. FAOSTAT. [http://faostat.fao.org/]

2. UN: World Urbanization Prospects, the 2009 Revision. New York: Department of Economic and Social Affairs, Population Division, United Nations; 2010.

3. Morton JF: The impact of climate change on smallholder and subsistence agriculture. Proc Natl Acad Sci U S A 2007, 104:19680-19680.

4. Smith LC, Subandoro A: Measuring Food Security Using Household Expenditure Surveys. Washington DC: International Food Policy Research Institute; 2007.

5. Headey D: Rethinking the global food crisis: the role of trade shocks. Food Policy 2011, 36:136-146.

6. FAO: Briefing paper: Hunger on the Rise: Soaring prices Add 75 Million People to Global Hunger Rolls. Rome; 2008.

7. FAO: Statistical yearbook. Rome: Food and Agriculture Organisation; 2010.

8. Duke and Duchess of Cambridge visit UNICEF's life-saving emergency supply centre in Copenhagen to highlight desperate plight of children in East Africa. [http://www.unicef.org/media/media_60370.html]

9. Von Braun J, Ahmed A: High Food Prices: The What, Who, and How of Proposed Policy Actions. Washington, DC: International Food Policy Research Institute; 2008

10. FAO, IFAD, IMF, OECD, UNCTAD, WFP, The-World-Bank, WTO, IFPRI, UNHLTF: Price Volatility in Food and Agricultural Markets: Policy Responses. Rome: Food and Agriculture Organisation; 2011.

11. Brown N, Laffan J, Wright M: High food prices, food security and the international trading system. In A paper presented to the Informa National Food Pricing Summit, Sydney, 29-30 September 2008. Canberra: Australian Government Department of Foreign Affairs and Trade; 2008.

12. Piesse J, Thirtle C: Three bubbles and a panic: an explanatory review of recent food commodity price events. Food Policy 2009, 34:119-129.

13. Gilbert CL, Morgan CW: Food price volatility. Phil Trans R Soc B Biol SC 2010, 365:3023-3034.

14. OECD, FAO: Agricultural Outlook 2011-2020. Paris: OECD Publishing: 2011

15. Bellemare MF: Rising Food Prices, Food Price Volatility, and Political Unrest. SSRN eLibrary 2011, 2011:2011.

16. Arezki R, Brückner M: Food prices and political instability. IMF Work Pap 2011, 11:1-22

17. Timmer CP: Reflections on food crises past. Food Policy 2010, 35:1-11.

18. Webb P: Medium to long-run implications of high food prices for global nutrition. J Nutr 2010, 140:1435-1475.

19. UN: World Population Prospects, the 2010 revision. New York: Department of Economic and Social Affairs, Population Division, United Nations; 2011.

20. FAO: Agriculture, food and water: a contribution to the World Water Development Report. Rome: FAO; 2003.

21. United Nations Convention to Combat Desertification: Desertification: a Visual Synthesis. Bonn, Germany: United Nations Convention to Combat Desertification; 2011.
22. Rosenzweig C, Iglesias A, Yang XB, Epstein PR, Chivian E: Climate change and extreme weather events; implications for food production, plant diseases, and pests. Global Change Hum Health 2001, 2:90-104.

23. Chen YC, Rogoff KS, Rossi B: Can exchange rates forecast commodity prices? Q J Econ 2010, 125:1145-1145.

24. Gilbert CL: How to understand high food prices. J Agric Econ 2010, 61:398-425.

25. Dwyer A, Gardner G, Williams T: Global Commodity Markets-Price Volatility and Financialisation. Sydney, Australia: Reserve Bank of Australia; 2011.

26. Instability indices and trends of free-market commodity prices for selected periods, annual, 1981-2010. [http://unctadstat.unctad.org/ TableViewer/tableView.aspx?Reportld=104]

27. Jacks DS, O'Rourke KH, Williamson JG: Commodity price volatility and world market integration since 1700. In National Bureau of Economic Research Working Paper Series. 2009. No. 14748.

28. Headey D, Fan S: Anatomy of a crisis: the causes and consequences of surging food prices. Agric Econ 2008, 39:375-391.

29. Rosegrant MW: 2020 Global Food Outlook: Trends, Alternatives, and Choices. Washington, DC: International Food Policy Research Institute; 2001.

30. Wright BD: The economics of grain price volatility. Appl Econ Perspect Pol 2011, 33:32-32.

31. Deaton A, Laroque G: Competitive storage and commodity price dynamics. J Polit Econ 1996, 104:896-923.

32. IEA, OECD: World Energy Outlook 2006. Paris: International Energy Agency; 2006

33. Boddiger D: Boosting biofuel crops could threaten food security. Lancet 2007, 370:923-924.

34. Tenenbaum DJ: Food vs. fuel: Diversion of crops could cause more hunger. Environ Health Perspect 2008, 116:A254-A254

35. Rajagopal D, Sexton SE, Roland-Holst D, Zilberman D: Challenge of biofuel: filling the tank without emptying the stomach? Environ Res Lett 2007, 2:1-9.

36. Lagi M, Bar-Yam Y, Bertrand KZ, Bar-Yam Y: The food crises: a quantitative model of food prices including speculators and ethanol conversion. New Engl Complex Syst Inst 2011, 4859:1-56.

37. Zhang Z, Lohr L, Escalante C, Wetzstein M: Food versus fuel: what do prices tell us? Energ Pol 2010, 38:445-451.

38. Mueller SA, Anderson JE, Wallington TJ: Impact of biofuel production and other supply and demand factors on food price increases in 2008. Biomass Bioenergy 2011, 35:1623-1632.

39. Historical selected agricultural commodities by State (1861 to Present). Catalogue Number 7124.0 edn. Canberra: Australian Bureau of Statistics, Australian Government.

40. WEA: Australian Wheat Industry Overview Fact Sheet, May 2007. Canberra: Australian Government Wheat Export Authority; 2007.

41. Chen J: Rapid urbanization in China: a real challenge to soil protection and food security. Catena 2007, 69:1-15.

42. Gilbert $\mathrm{CL}$ : The impact of exchange rates and developing country debt on commodity prices. Econ J 1989, 99:773-784.

43. Baffes J: Explaining stationary variables with non-stationary regressors Appl Econ Lett 1997, 4:69-75.

44. Mitchell D: A Note on Rising Food Prices. Washington, D.C., USA: World Bank Development Economics Group; 2008

45. Gilbert CL: Commodity Speculation and Commodity Investment. Geneva, Switzerland: Department of Economics, University of Trento, Italia; 2008.

46. Timmer CP: Chapter 2.3 Causes of high food prices. In Asian Development Outlook Update (September). Manilla, The Philippines: Asian Development Bank. 2008:72-93.

47. Jian Y, Balyeat BR, Leatham DJ: Futures trading activity and commodity cash price volatility. J Bus Finance Account 2005, 32:297-323.

48. Robles M, Torero M, Von Braun J: When speculation matters. IFPRI Issue Brief 57: International Food Policy Research Institute; 2009.

49. Pace N, Seal A, Costello A: Food commodity derivatives: a new cause of malnutrition? Lancet 2008, 371:1648-1650.

50. Irwin SH, Sanders DR, Merrin RP: Devil or angel? The role of speculation in the recent commodity price boom (and bust). J Agr Appl Econ 2009, 41:377-391.

51. Sanders DR, Irwin SH: A speculative bubble in commodity futures prices? Cross-sectional evidence. Agric Econ 2010, 41:25-32.

52. Bartlett AA: Forgotten fundamentals of the energy crisis. Am J Phys 1978, 46:876-888.

53. Attarian J: The coming end of cheap oil. Social Contract J 2002, 12(4) [http://www.thesocialcontract.com/artman2/publish/tsc1204/article_1095.shtml] 
54. Wright J: Sustainable Agriculture and Food Security in an Era of Oil Scarcity: Lessons from Cuba. London: Earthscan/James \& James; 2009.

55. Hamer $E$, Anslow M: Ten reasons why organic farming can feed the world. Ecologist 2008, 38:43-46.

56. Baffes J: Oil spills on other commodities. Resour Pol 2007, 32:126-134.

57. Ninno C, Dorosh PA: Averting a food crisis: private imports and public targeted distribution in Bangladesh after the 1998 flood. Agric Econ 2001, 25:337-346.

58. Richards T, Rosewall T: Measures of underlying inflation. Reserve Bank of Australia Bulletin 2010, March Quarter:7-12.

59. Green Y, Williams J: An Examination of operating costs within a state's restaurant industry. University of Nevada: In Caesars Hospitality Research Summit; Los Vegas; 2010.

60. Ash A, Mclntosh P, Cullen B, Carberry P, Stafford Smith M: Constraints and opportunities in applying seasonal climate forecasts in agriculture. Aust J Agric Res 2007, 58:952-965.

61. Brunner AD: El Nino and world primary commodity prices: warm water or hot air? Rev Econ Stat 2002, 84:176-183.

62. Hansen JW, Jones JW, Kiker CF, Hodges AW: El Niño-Southern Oscillation impacts on winter vegetable production in Florida. J Clim 1999, 12:92-102

63. Berry BJL, Okulicz-Kozaryn A: Are there ENSO signals in the macroeconomy? Ecol Econ 2008, 64:625-633.

64. Schmidhuber J, Tubiello FN: Global food security under climate change. Proc Natl Acad Sci U S A 2007, 104:19703-19708.

65. Rosenzweig C, Parry ML: Potential impact of climate change on world food supply. Nature 1994, 367:133-138.

66. Fischer $\mathrm{G}$, Shah M, van Velthuizen H: Climate Change and Agricultural Vulnerability. New York: International Institute for Applied Systems Analysis; 2002.

67. Parry ML, Rosenzweig C, Iglesias A, Livermore M, Fischer G: Effects of climate change on global food production under SRES emissions and socio-economic scenarios. Global Environ Change 2004, 14:53-67.

68. Ericksen PJ, Ingram JSI, Liverman DM: Food security and global environmental change: emerging challenges. Environ Sci Pol 2009, 12:373-377.

69. IWMI: Water for food, water for life: A comprehensive assessment of water management in agriculture. London: Earthscan; 2007.

70. Rosegrant MW, Cai X, Cline SA: Global Water Outlook to 2025: Averting an Impending Crisis. Washington DC: International Food Policy Research Institute; 2002

71. Ministerial declaration: Action plan on food price volatility and agriculture. In Meeting of G20 Agriculture Ministers Paris 22-23 June. Edited by. [http://agriculture.gouv.fr/IMG/pdf/2011-06-23_-_Action_Plan_-_VFinale.pdf]

72. The Cannes Summit Final Declaration - Building our common future: Renewed collective action for the benefit of all. [http://www.g20-g8.com/ g8-g20/g20/english/for-the-press/news-releases/cannes-summit-finaldeclaration.1557.html]

73. Boto I, Lopes I: Food price volatility: Implications for ACP countries. Briefing number 25. Brussels: Brussels Development Briefings; 2011

74. FAO: How to feed the world in 2050. Rome: Food and Agriculture Organisation; 2009

75. Akroyd S, Smith L: Review of Public Spending to Agriculture. Washington DC: Department for International Development and the World Bank; 2007.

76. Eicher CK, Staatz JM: Agricultural development in the Third World. Johns Hopkins University Press; 1990.

77. Collier P, Dollar D: Development effectiveness: what have we learnt? Econ J 2004, 114:244-271.

78. Alston JM, Pardey PG, Piggott RR: Synthesis of Themes and Policy Issues. In Agricultural $R$ and D in the Developing World: Too Little, Too Late? International Food Policy Research Institute. 2006:361-375.

79. Research Institute IFP: African Agricultural $R$ and D in the New Millennium: Progress for Some, Challenges for Many. Washington, DC: International Food Policy Research Institute; 2011.

80. Schmidhuber JJB, Boedeker G: Capital requirements for agriculture in developing countries to 2050. In FAO Expert Meeting on "How to Feed the World in 2050". Edited by. Rome: FAO; 2009.
81. Agricultural Market Information System. [http://www.amis-outlook.org]

82. Rosenzweig C, Wilbanks TJ: The state of climate change vulnerability, impacts, and adaptation research: strengthening knowledge base and community. Clim Change 2010, 100:103-106.

83. Rötter RP, Carter TR, Olesen JE, Porter JR: Crop-climate models need an overhaul. Nat Clim Change 2011, 1:175-177.

84. AGMIP: The Agricultural Model Intercomparison and Improvement Project. New York: Columbia University; 2011.

85. UN: Global Pulse Analytical Workshop Pocantico Hills, 8-10 September. New York: United Nations; 2010

86. Daily tracking of commodity prices: The e-Bread Index. [http://www. unglobalpulse.org]

87. Global agricultural monitoring for enhancing food security. [www. planetaryskin.org]

88. Mithal V, Garg A, Boriah S, Steinbach M, Kumar V, Potter C, Klooster S, Castilla-Rubio JC: Monitoring global forest cover using data mining. ACM Trans Intell Syst Technol 2011, 2:1-22.

89. Barrett CB, Maxwell DG: Towards a global food aid compact. Food Policy 2006, 31:105-118.

90. Food Aid Information System. [http://www.wfp.org/fais/]

91. Barrett CB: Food Aid Effectiveness: "t's the Targeting, Stupid!". New York: Cornell University Department of Applied Economics and Management; 2002.

92. Jayne TS, Strauss J, Yamano T, Molla D: Giving to the poor? Targeting of food aid in rural Ethiopia. World Dev 2001, 29:887-910.

93. Barrett $C B$, Heisey $\mathrm{KC}$ : How effectively does multilateral food aid respond to fluctuating needs? Food Policy 2002, 27:477-491.

94. Young LM, Abbott PC: Food aid donor allocation decisions after 1990. Can J Agr Econ Rev 2008, 56:27-50.

95. The-World-Bank: World Development Report 1990. London: Oxford University Press; 1990.

96. Devereux S: Can social safety nets reduce chronic poverty? Dev Pol Rev 2002, 20:657-675.

97. Barrett CB, Maxwell DG: Food Aid After Fifty Years: Recasting its Role. Abingdon, UK: Routledge; 2005

98. FAO: The State of Food and Agriculture: Food Aid for Food Security? Rome: Food and Agriculture Organisation; 2006.

99. Paarlberg RL: Governance and Food Security in an Age of Globalization. Washington, USA: International Food Policy Research Institute; 2002.

100. Sahley C, Groelsema B: Marchione T. Nelson D: The Governance Dimensions of Food Security in Malawi. USAID; 2005

101. Maxwell D: The political economy of urban food security in Sub-Saharan Africa. World Dev 1999, 27:1939-1953.

102. Jha S, Srinivasan PV: Liberalized trade and domestic price stability. The case of rice and wheat in India. J Dev Econ 2001, 65:417-441.

103. Pinckney TC: Is market liberalisation compatible with food security? Food Policy 1993, 18:325-333.

104. Dorosh PA: Trade liberalisation and national food security: rice trade between Bangladesh and India. World Dev 2001, 29:673-689.

105. David D: How far down the path to free trade? The importance of rice price stabilization in developing Asia. Food Policy 2001, 26:163-175.

106. Beddington J, Asaduzzaman M, Fernández A, Clark M, Guillou M, Jahn M, Erda L, Mamo T, Van Bo N, Nobre C, Scholes R, Sharma R, Wakhungu J: Achieving food security in the face of climate change. In Final report from the Commission on Sustainable Agriculture and Climate Change. Copenhagen, Denmark: CGIAR Research Program on Climate Change, Agriculture and Food Security (CCAFS); 2012

doi:10.1186/2048-7010-1-8

Cite this article as: Hajkowicz et al.: Food price volatility and hunger alleviation - can Cannes work?. Agriculture \& Food Security 2012 1:8. 